\title{
The Detrimental Effect of Depression, Anxiety \& Stress on Under-Graduates, Post-Graduates, and Freshly Graduates Students and Their Psychological Distress Triggered by COVID-19 Crisis
}

\author{
Nijal Parmar ${ }^{1}$, Vicky Kasundra ${ }^{2}$, Anand Vaghasiya ${ }^{3}$, Dimpal Paija ${ }^{4}$ \\ ${ }^{1}$ Assistant Professor in S S Agrawal Institute of Physiotherapy and Medical Care Education, Agrawal College \\ Campus, Near Devina Park Society, Veeranjali Marg Grid Road, Navsari \\ ${ }^{2}$ Therapist in the Touch of Healing, Rehabilitation Center \\ ${ }^{3,4}$ Therapist in Vyom Advanced Pain and Sports Clinic \\ Corresponding Author: Nijal Parmar
}

\begin{abstract}
Background: Heightened psychological rate for college students suffering and negative academic implications downstream are common under normal circumstances. One published research has looked at the effects to date COVID19 on schooling and health for the students (Cao 2020 et al.). About 25 percent of the sample recorded getting signs of anxiety which were optimistic correlated with greater academic issues delays, economic implications, and impacts of the pandemic everyday life. The study's goal, therefore, is to find out the impact of the pandemic on mental health \& psychological distress on students going to college.
\end{abstract}

Results: Of the 948 participants, most students and recent graduates did not have psychological symptoms such as depression, anxiety, and discomfort, but half had psychological distress (Female=195 \& male=97). Although the majority of 20-23-year-old students reported moderate psychological distress and 189 undergraduates had a serious psychological distress experience. The gender ratio was not equal in our sample so 300 participants were chosen at random and assessed afterward. Results show that post-graduate females and freshly graduates male participants have more psychological distress among 300 participants.

Conclusion: The COVID 19 outbreak was associated with mild to moderate depression, anxiety, and stress among college students, but most students experienced no mental health symptoms, although half of the students were seriously impacted by the COVID-19 outbreak and had a significant negative effect on their student psychological status.

Keywords: COVID-19, DASS-21, IES-Revised scale

\section{INTRODUCTION}

Covid-19, widely known as the novel Coronavirus, is thought to have emerged from a wet market in Wuhan, China, and has terrifically affected the world that it becomes even difficult to breathe ${ }^{[1-3]}$. By July 31, 2020, due to the convergence of this uncontrollable infectious disease, more than 17,752,708 (World meter 2020) people were infected globally ${ }^{[1]}$. At present, the condition has become worrying with no medication or vaccine available for Covid-19 ${ }^{[3]}$. To avoid the mass spread of this pandemic virus, a national lockdown decision was taken. No doubt, it will save the lives of the people. However, this lockdown also creates chaos for the people and enormous difficulties ${ }^{[1]}$.

Pandemics have not only influenced mortality morbidity but have also disrupted the lifestyle, daily routine, industry, stock market, and even the world's education system. This pandemic has greatly impacted 
the Indian academic fraternity. Academic fraternity is under insurmountable mental strain due to scrupulous isolation steps and the closed-down of universities and colleges, which raise the prevalence and incidence of stress, anxiety, and depression among students ${ }^{[1]}$. Many studies reported among all general population, students have widely affected their mental health and psychological status. One study was done on stress among the general population revealed that $63.2 \%$ of students are having moderate stress levels among the general population in India ${ }^{[4]}$. The Student's mental health is a matter of concern worldwide. The student's entire success depends on his / her mental health. Mental health problems not only harm the individual student but also have a significant negative impact on the society, as today's student is the country's future that contributes to its growth by performing various roles such as teachers, engineers, physicians, nurses, etc. Therefore, the student's mental health must be given the greatest importance ${ }^{[5]}$.

American college health association reported that college students have heightened their stress level \& anxiety level due to social isolation and the global outbreak of COVID 19. Because of these changes in college students, educational organization have accepted emergency online learning formats and that can be a burden to students as well as teachers ${ }^{[6]}$.

As the government had no choice instead of implementation lockdown in the country. So, the government's first step was to get closer to the country's school and college and empty the hostels. Because of this, each student has to rush out in very short periods to their hometowns and home states, which has stressed the safety of both students and their parents while traveling ${ }^{[7]}$. Also, the authorities advised the teaching fraternity to take their classes online because of the lockdown problem and to preserve social distance. It is very difficult to plan and provide quality lectures to the students during this pandemic, and the situation gets worse when the teaching is online because most of the cheers have not been equipped to efficiently use web teaching tools. Furthermore, teachers who are trained in traditional teaching have found it harder to cope with online approaches, thus making students more stressed $^{[1]}$.

Students around the world are also in distress due to the uncertainty of exams in their schools and colleges and the shortage of jobs, etc ${ }^{[3]}$. Besides, due to this zoonotic virus, various forms of exams have been delayed and there is total confusion about the examination policies, i.e. how and when it will be performed. In addition to the regular exams, much of the competitive exam was also aborted or deferred for which students studied for the last few months or even a year ${ }^{[1]}$. UGC has declared the academic schedule for the Final year in which they have strictly mentioned that Final year students have to give exams and they will not get mass promotion like the first second or third-year students ${ }^{[8]}$. To this parents will add more stress to their children because they are equally worried about their children's careers ${ }^{[5]}$. The postponement of the exams induces annoyance, too, and Stress among students. The rapid dissemination of fake news through social networks (WhatsApp, Twitter, and Facebook) has created confusion and a stressful environment for the students ${ }^{[1]}$. These various forms of stress perturb the mental health of the students and thus make them more anxious or de-pressed. Because of all major risk factors being present in the vulnerable group which has in-creased suicidal attempts in India. According to THE ECONOMIC TIMES, 300 people have attempted suicide due to COVID 19 and stress or another disruptive psychological state even they have disclosed that many companies. It is likely that 60 $65 \%$ of interviews are delayed in the short term, particularly in the service sector, and that interviews following the recession across industries caused by the coronavirus pandemic have been canceled ${ }^{[9]}$. One pilot study conducted on a media report about 
Nijal Parmar et.al. The detrimental effect of depression, anxiety \& stress on under-graduates, post-graduates, and freshly graduates students and their psychological distress triggered by COVID-19 crisis.

suicidal attempts in India has reported that Four victims were suffering from depression based on their relatives, and three victims were having alcohol dependence with withdrawal symptoms ${ }^{[10]}$. Therefore the present survey was intended to assess the depression, anxiety, and stress level in undergraduates, postgraduates, and freshly graduate students whether it can be affected their mental health or not due to COVID 19.

\section{MATERIALS AND METHOD}

The observational study was implemented in the subjects who were studying in different colleges, universities, and institutions were taken as the research population. For this non-probability snowball sampling technique was employed. Because of the lockdown, the respondents were invited remotely and they only completed the questionnaire in English via an online platform. The questionnaire approach was used to collect data where the Google form was generated and distributed on various platforms such as WhatsApp groups, Facebook, and Instagram, etc. The consent was also taken from the student's ways of using their data in the study with the aid of Google forms. The questionnaire was completely voluntary and noncommercial. Using SPSS version 20, and Microsoft excel 2016 the data was analyzed.

\section{INCLUSION CRITERIA}

- Participants age from 18 to 27 .

- Participants who just pass out and got a job within 1 year.

- Subjects who are willingly participating in the study.

\section{FINDINGS:}

Data analysis was done using the SPSS software (version 20.0) and Microsoft excel 2016. Results were considered a significant level at $\mathrm{p}<0.05$ and a confidence interval of $95 \%$.

\section{Phase 1: overall analysis of 948 respondents}

(1). Survey Respondents: Out of 996 respondents, only 960 were agreed to complete the survey \& out of 960 respondents, 948 were selected in the study (12 were excluded due to their age). 235 male and 713 female participants were selected based on inclusion and exclusion criteria. A total of 996 participants were invited virtually but only 948 subjects have completed the survey. Of these 52 subjects were excluded (12 were not included due to their age, 36 were not willingly participated). For the total number of participants, 235 were male, 713 were female. Participant's mean age was found to be 21.19. From the sample 631 were undergraduates, 188 were fresh graduates (up to 1 year), and 129 postgraduates. For this study students from the various streams are included i.e. medical, paramedical, engineer, arts, commerce, science, etc.

Table 1: Demographic characteristics of Respondent

\begin{tabular}{|c|c|c|c|}
\hline Variable & Category & N & Percentage(\%) \\
\hline Sex & Male & 235 & $24.80 \%$ \\
\hline & Female & 713 & $75.20 \%$ \\
\hline & & 948 & $100 \%$ \\
\hline Age categories & $18-19$ & 167 & $17.6 \%$ \\
\hline & $20-21$ & 372 & $39.2 \%$ \\
\hline & $22-23$ & 322 & $34 \%$ \\
\hline & $24-25$ & 79 & $8.3 \%$ \\
\hline & $26-27$ & 8 & $0.8 \%$ \\
\hline Education Level & & 948 & $100 \%$ \\
\hline & Under Graduates & 631 & $66.6 \%$ \\
\hline & Post Graduates & 188 & $19.8 \%$ \\
\hline & Freshly & 129 & $13.6 \%$ \\
\hline Praduates & & \\
\hline & & 948 & $100 \%$ \\
\hline & Urban & 697 & $73.5 \%$ \\
\hline & Rural & 251 & $26.5 \%$ \\
\hline & & 948 & $100 \%$ \\
\hline
\end{tabular}

Table 1 shows the population of the students in age categories, their education level, and their place of residence.

Table 2 shows out of 948 respondents, 136(14.3\%) respondents were reported mild psycho-logical impact, $49(5.2 \%)$ were considered to have a moderate, and 292(30.8\%) having Severe psychological impact on their mental state. For measuring the Mental health of college students, Depression, Anxiety, and Stress 
Nijal Parmar et.al. The detrimental effect of depression, anxiety \& stress on under-graduates, post-graduates, and freshly graduates students and their psychological distress triggered by COVID-19 crisis.

level were checked by using DASS 21 item scale in which 91 respondents were having mild depression (Score: 10-12), 131 respondents were considered to have a moderate depression (Score: 13-20), and only 10 respondents having severe depression (score: 27-42). For Anxiety level, 110 respondents were having mild anxiety (Score: 11-18) and only 9 were having moderate anxiety (score: 19-26). For stress level, 173(18.7\%) respondents were considered to have mild stress (Score: 11-
18), and only 19 respondents have reported moderate stress (score: 19-26).To check the psychological impact of the COVID 19 outbreak, $471(49.7 \%)$ were reported not to have psychological distress due to COVID 19(score: 0-24), but 136(14.3\%) were considered to have mild psychological distress (score: 24-32), 49(5.2\%) were reported moderate psychological distress (Score: 33-36) but 292 respondents were suffering from severe psychological distress due to COVID-19.

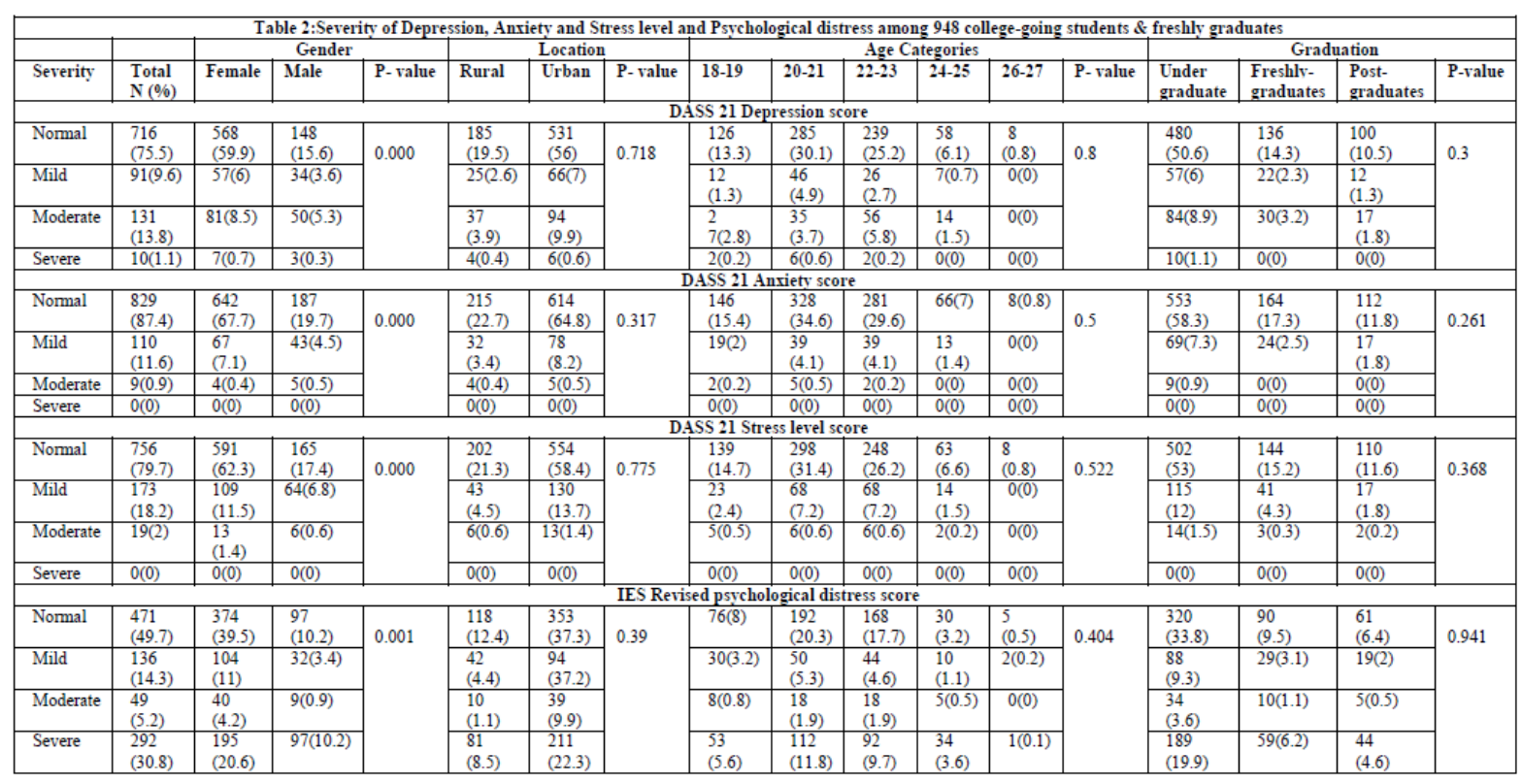

(2) Sociodemographic characteristics, mental health among college-going students (DASS 21 item Scale) and the psychological impact of the outbreak (IES-Revised Scale): (Table No.2)

Table 2 shows $57(6.1 \%)$ female students \& 34(3.6\%) male respondents having mild depression among 713 and 235 females \& males respectively. But $81(8.5 \%)$ females \& 50(5.3\%) males were considered to have moderate depression and only 7 females and 3 males were having severe depression level among $713 \& 235$ total female \& males respondents. For anxiety level in the table 2 shows $67(7.1 \%)$ females $\& 43(4.5 \%)$ males were suffering from mild anxiety, and only 4 female \& 5 male respondents having moderate anxiety levels. For stress level, 109 females and 64 males were suffering from mild stress and only 13 females \& 6 male respondents were considered to have a moderate stress level among 713 females and 235 male respondents. Pearson chi-square test shows the significance level is 0.000 which indicates there is a high significance association between gender and DASS 21 sub-scale. Total 195 female and 97 male respondents were having severe psychological distress due to COVID 19 outbreak. In the age group 22-23-year-old students, 56 were suffering from moderate depression compared to other age groups. Anxiety level was high in age group 22-23year-old students. Among all age groups, age group 20-21 and 22-23 year old $112 \&$ 92 students were considered to have severe psychological distress. In table 2 shows 84 
Nijal Parmar et.al. The detrimental effect of depression, anxiety \& stress on under-graduates, post-graduates, and freshly graduates students and their psychological distress triggered by COVID-19 crisis.

undergraduate students having moderate depression levels among other graduate students. Same as depression level, 69 respondents having mild anxiety and 115 respondents were considered to have a mild stress level in undergraduate students. 189 undergraduates and 59 freshly graduates were considered to have severe psychological distress compared to postgraduate students and their only a few respondents having a mild and moderate score of IES-Revised scale compared to severely affected respondents. Compared to the rural area, 94 students were living in the urban area suffering from moderate depression, 78 were considered to have a moderate anxiety level and 130 respondents were having moderate stress levels. In comparison to the rural area, 94, 39, and 211 respondents were considered to have mild, moderate, and severe psychological distress in students who were living in urban areas.

(4). Scores of depression, anxiety, stress, and psychological impact of the outbreak in comparison to female and male students in different age groups and graduation of 948 students: (Table $3 \& 4$ )

Table 3: Score of gender in relation to age categories in mental health and psychological dis-tress among 948 students $\&$ freshly graduates

\begin{tabular}{|c|c|c|c|c|c|c|c|c|c|c|c|c|}
\hline \multirow[t]{2}{*}{ Variables } & \multicolumn{2}{|c|}{ Normal } & \multicolumn{2}{|c|}{ Mild } & \multicolumn{2}{|c|}{ Moderate } & \multirow{2}{*}{\multicolumn{2}{|c|}{ Severe }} & \multirow{2}{*}{\multicolumn{2}{|c|}{ P-value }} & \multirow{2}{*}{\multicolumn{2}{|c|}{$\begin{array}{c}\text { Pearson chi } \\
\text { square value }\end{array}$}} \\
\hline & \multicolumn{6}{|c|}{ DASS 21 Depression level } & & & & & & \\
\hline $\begin{array}{l}\text { Age } \\
\text { Categories }\end{array}$ & Female & Male & Female & Male & Female & Male & Female & Male & Female & Male & Female & Male \\
\hline 18-19 & 95 & 31 & 8 & 4 & 16 & 11 & 2 & 0 & \multirow[t]{5}{*}{0.426} & \multirow[t]{5}{*}{0.304} & \multirow[t]{5}{*}{12.242} & \multirow[t]{5}{*}{13.941} \\
\hline $20-21$ & 227 & 58 & 28 & 18 & 21 & 14 & 3 & 3 & & & & \\
\hline $22-23$ & 193 & 46 & 15 & 11 & 36 & 19 & 2 & 0 & & & & \\
\hline $24-25$ & 48 & 10 & 6 & 1 & 8 & 6 & 0 & 0 & & & & \\
\hline $26-27$ & 5 & 3 & 0 & 0 & 0 & 0 & 0 & 0 & & & & \\
\hline \multicolumn{13}{|c|}{ DASS 21 Anxiety level } \\
\hline $18-19$ & 108 & 38 & 11 & 8 & 2 & 0 & 0 & 0 & \multirow[t]{5}{*}{0.578} & \multirow[t]{5}{*}{0.247} & \multirow[t]{5}{*}{6.625} & \multirow[t]{5}{*}{10.269} \\
\hline $20-21$ & 250 & 78 & 28 & 11 & 1 & 4 & 0 & 0 & & & & \\
\hline $22-23$ & 226 & 55 & 19 & 20 & 1 & 1 & 0 & 0 & & & & \\
\hline $24-25$ & 53 & 13 & 9 & 4 & 0 & 0 & 0 & 0 & & & & \\
\hline $26-27$ & 5 & 3 & 0 & 0 & 0 & 0 & 0 & 0 & & & & \\
\hline \multicolumn{13}{|c|}{ DASS 21 Stress level } \\
\hline $18-19$ & 103 & 36 & 14 & 9 & 4 & 1 & 0 & 0 & \multirow[t]{5}{*}{0.461} & \multirow[t]{5}{*}{0.533} & \multirow[t]{5}{*}{7.72} & \multirow[t]{5}{*}{7.033} \\
\hline $20-21$ & 236 & 62 & 41 & 27 & 2 & 4 & 0 & 0 & & & & \\
\hline $22-23$ & 198 & 50 & 43 & 25 & 5 & 1 & 0 & 0 & & & & \\
\hline $24-25$ & 49 & 14 & 11 & 3 & 2 & 0 & 0 & 0 & & & & \\
\hline $26-27$ & 5 & 3 & 0 & 0 & 0 & 0 & 0 & 0 & & & & \\
\hline \multicolumn{13}{|c|}{ IES Revised Scale } \\
\hline $18-19$ & 54 & 22 & 24 & 6 & 6 & 2 & 37 & 16 & \multirow[t]{5}{*}{0.327} & \multirow[t]{5}{*}{0.644} & \multirow[t]{5}{*}{13.607} & \multirow[t]{5}{*}{12.531} \\
\hline $20-21$ & 155 & 37 & 38 & 12 & 15 & 3 & 71 & 41 & & & & \\
\hline $22-23$ & 136 & 32 & 33 & 11 & 15 & 3 & 62 & 30 & & & & \\
\hline $24-25$ & 27 & 3 & 7 & 3 & 4 & 1 & 24 & 10 & & & & \\
\hline $26-27$ & 2 & 3 & 2 & 0 & 0 & 0 & 1 & 0 & & & & \\
\hline
\end{tabular}

Table 3 shows the majority of students had no psychological symptoms which can be affected their mental health but in 20 to 23-year-old female students having a moderate depression level compared to other age categories. Likewise, female students who are 22 to 23 years old had severe psychological distress compared to males but the male respondents who are in a category of 20-21 years had an experienced of severe psychological distress compared to other age categories.

Table 4 shows in which graduation category students had more psychological issues among 713 females and 235 males students. Similar to age categories, Undergraduates females had a moderate depression level and had a mild anxiety and stress level compared to male students and freshly graduates \& postgraduate females. 
Nijal Parmar et.al. The detrimental effect of depression, anxiety \& stress on under-graduates, post-graduates, and freshly graduates students and their psychological distress triggered by COVID-19 crisis.

Table 4: Score of gender in relation to graduation in mental health and psychological distress among 948 students \& freshly graduates

\begin{tabular}{|c|c|c|c|c|c|c|c|c|c|c|c|c|}
\hline \multirow{3}{*}{$\begin{array}{c}\text { Variables } \\
\text { Graduation }\end{array}$} & \multicolumn{2}{|c|}{ Normal } & \multicolumn{2}{|c|}{ Mild } & \multicolumn{2}{|c|}{ Moderate } & \multirow{2}{*}{\multicolumn{2}{|c|}{ Severe }} & \multirow{2}{*}{\multicolumn{2}{|c|}{ P value }} & \multirow{2}{*}{\multicolumn{2}{|c|}{$\begin{array}{l}\text { Pearson's chi } \\
\text { square value }\end{array}$}} \\
\hline & \multicolumn{6}{|c|}{ DASS 21 Depression level } & & & & & & \\
\hline & Female & Male & Female & Male & Female & Male & Female & Male & Female & Male & Female & Male \\
\hline Undergraduates & 381 & 99 & 39 & 18 & 51 & 33 & 7 & 3 & \multirow[t]{3}{*}{0.647} & \multirow[t]{3}{*}{0.432} & \multirow[t]{3}{*}{4.22} & \multirow[t]{3}{*}{5.923} \\
\hline $\begin{array}{l}\text { Freshly } \\
\text { graduates }\end{array}$ & 107 & 29 & 10 & 12 & 18 & 12 & 0 & 0 & & & & \\
\hline Postgraduates & 80 & 20 & 8 & 4 & 12 & 5 & 0 & 0 & & & & \\
\hline \multicolumn{13}{|c|}{ DASS 21 Anxiety level } \\
\hline $\begin{array}{l}\text { Under } \\
\text { graduates }\end{array}$ & 432 & 121 & 42 & 27 & 4 & 5 & 0 & 0 & \multirow[t]{3}{*}{0.448} & \multirow[t]{3}{*}{0.436} & \multirow[t]{3}{*}{3.7} & \multirow[t]{3}{*}{3.781} \\
\hline $\begin{array}{l}\text { Freshly } \\
\text { graduates }\end{array}$ & 123 & 41 & 12 & 12 & 0 & 0 & 0 & 0 & & & & \\
\hline Postgraduates & 87 & 25 & 13 & 4 & 0 & 0 & 0 & 0 & & & & \\
\hline \multicolumn{13}{|c|}{ DASS 21 stress level } \\
\hline $\begin{array}{l}\text { Under } \\
\text { graduates }\end{array}$ & 397 & 105 & 73 & 42 & 8 & 6 & 0 & 0 & \multirow[t]{3}{*}{0.919} & \multirow[t]{3}{*}{0.122} & \multirow[t]{3}{*}{0.937} & \multirow[t]{3}{*}{7.266} \\
\hline $\begin{array}{l}\text { Freshly } \\
\text { graduates }\end{array}$ & 109 & 35 & 23 & 18 & 3 & 0 & 0 & 0 & & & & \\
\hline Postgraduates & 85 & 25 & 13 & 4 & 2 & 0 & 0 & 0 & & & & \\
\hline \multicolumn{13}{|c|}{ IES Revised Score } \\
\hline $\begin{array}{l}\text { Under } \\
\text { graduates }\end{array}$ & 252 & 68 & 73 & 15 & 29 & 5 & 124 & 65 & \multirow[t]{3}{*}{0.754} & \multirow[t]{3}{*}{0.304} & \multirow[t]{3}{*}{3.425} & \multirow[t]{3}{*}{7.182} \\
\hline $\begin{array}{l}\text { Freshly } \\
\text { graduates }\end{array}$ & 72 & 18 & 19 & 10 & 7 & 3 & 37 & 22 & & & & \\
\hline Postgraduates & 50 & 11 & 12 & 7 & 4 & 1 & 34 & 10 & & & & \\
\hline
\end{tabular}

Phase 2: To generalise the results according to the graduation of students:

The statistical analysis was done

based on student's graduation for generalisation of results as the population of fresh graduates, postgraduates and undergraduates are not equal so random-ly 100 samples were extracted from 948 respondents and compare the depression, anxiety, and stress level as well as psychological impact of the outbreak.

Table 5: Score of gender in relation to age categories in mental health and psychological dis-tress of 300 students \& freshly graduates

\begin{tabular}{|c|c|c|c|c|c|c|c|c|c|c|c|c|}
\hline \multirow[t]{2}{*}{ Variables } & \multirow{2}{*}{\multicolumn{8}{|c|}{\begin{tabular}{l|r} 
Mild & Moderate \\
DASS 21 Depression level
\end{tabular}}} & \multirow{2}{*}{\multicolumn{2}{|c|}{$P$ value }} & \multirow{2}{*}{\multicolumn{2}{|c|}{$\begin{array}{l}\text { Pearson's chi } \\
\text { sqaure value }\end{array}$}} \\
\hline & & & & & & & & & & & & \\
\hline $\begin{array}{l}\text { Age } \\
\text { Categories }\end{array}$ & \multicolumn{4}{|c|}{\begin{tabular}{|c|c}
\multicolumn{2}{c}{ DASS 21 I } \\
Female & Male
\end{tabular}} & Female & Male & Female & Male & Female & Male & Female & Male \\
\hline 18-19 & 17 & 4 & 1 & 1 & 4 & 2 & 1 & 0 & \multirow[t]{5}{*}{0.847} & \multirow[t]{5}{*}{0.067} & \multirow[t]{5}{*}{7.152} & \multirow[t]{5}{*}{19.986} \\
\hline $20-21$ & 42 & 9 & 4 & 10 & 7 & 2 & 1 & 2 & & & & \\
\hline $22-23$ & 83 & 23 & 6 & 6 & 15 & 6 & 0 & 0 & & & & \\
\hline $24-25$ & 31 & 5 & 4 & 0 & 5 & 4 & 0 & 0 & & & & \\
\hline 26-27 & 3 & 2 & 0 & 0 & 0 & 0 & 0 & 0 & & & & \\
\hline \multicolumn{10}{|c|}{ DASS 21 Anxiety level } & & & \\
\hline 18-19 & 20 & 5 & 3 & 2 & 0 & 0 & 0 & 0 & \multirow[t]{5}{*}{0.934} & \multirow{5}{*}{0.424} & \multirow[t]{5}{*}{0.831} & \multirow[t]{5}{*}{8.094} \\
\hline $20-21$ & 48 & 19 & 6 & 2 & 0 & 2 & 0 & 0 & & & & \\
\hline $22-23$ & 92 & 27 & 12 & 8 & 0 & 0 & 0 & 0 & & & & \\
\hline $24-25$ & 34 & 6 & 6 & 3 & 0 & 0 & 0 & 0 & & & & \\
\hline 26-27 & 3 & 2 & 0 & 0 & 0 & 0 & 0 & 0 & & & & \\
\hline \multicolumn{10}{|c|}{ DASS 21 Stress level } & & & \\
\hline 18-19 & 17 & 5 & 5 & 2 & 1 & 0 & 0 & 0 & \multirow[t]{5}{*}{0.934} & \multirow[t]{5}{*}{0.571} & \multirow[t]{5}{*}{3.005} & \multirow[t]{5}{*}{6.683} \\
\hline $20-21$ & 44 & 12 & 10 & 9 & 0 & 2 & 0 & 0 & & & & \\
\hline $22-23$ & 83 & 24 & 19 & 11 & 2 & 0 & 0 & 0 & & & & \\
\hline $24-25$ & 31 & 6 & 8 & 3 & 1 & 0 & 0 & 0 & & & & \\
\hline 26-27 & 3 & 2 & 0 & 0 & 0 & 0 & 0 & 0 & & & & \\
\hline \multicolumn{10}{|c|}{ IES Revised Scale } & & & \\
\hline 18-19 & 8 & 3 & 4 & 1 & 2 & 1 & 9 & 2 & \multirow[t]{5}{*}{0.104} & \multirow[t]{5}{*}{0.034} & \multirow[t]{5}{*}{18.412} & \multirow[t]{5}{*}{22.359} \\
\hline $20-21$ & 23 & 5 & 10 & 5 & 2 & 1 & 19 & 12 & & & & \\
\hline $22-23$ & 59 & 20 & 14 & 3 & 3 & 0 & 28 & 12 & & & & \\
\hline $24-25$ & 15 & 0 & 4 & 3 & 4 & 0 & 17 & 6 & & & & \\
\hline 26-27 & 0 & 2 & 2 & 0 & 0 & 0 & 1 & 0 & & & & \\
\hline
\end{tabular}

Table 5 shows the majority of females participants had a more issue compared to males and half of the student population had no experienced of major 
Nijal Parmar et.al. The detrimental effect of depression, anxiety \& stress on under-graduates, post-graduates, and freshly graduates students and their psychological distress triggered by COVID-19 crisis.

depression, anxiety, and stress problems but few male respondents showed severe depression and moderate anxiety \& stress level in the age categories of 20-21 compared to other age groups.

Table 6: Score of gender in relation to graduation in mental health and psychological distress of 300 students \& freshly graduates

\begin{tabular}{|c|c|c|c|c|c|c|c|c|c|c|c|c|}
\hline \multirow[t]{2}{*}{ Variables } & \multicolumn{2}{|c|}{ Normal } & \multicolumn{2}{|c|}{ Mild } & \multicolumn{2}{|c|}{ Moderate } & \multicolumn{2}{|c|}{ Severe } & \multirow{2}{*}{\multicolumn{2}{|c|}{ P value }} & \multirow{2}{*}{\multicolumn{2}{|c|}{$\begin{array}{l}\text { Pearson's chi } \\
\text { sqaure value }\end{array}$}} \\
\hline & \multicolumn{8}{|c|}{ DASS 21 Depression level } & & & & \\
\hline Graduation & Female & Male & Female & Male & Female & Male & Female & Male & Female & Male & Female & Male \\
\hline Undergraduates & 61 & 14 & 4 & 5 & 9 & 3 & 2 & 2 & \multirow[t]{3}{*}{0.584} & \multirow[t]{3}{*}{0.222} & \multirow[t]{3}{*}{4.688} & \multirow[t]{3}{*}{8.224} \\
\hline $\begin{array}{l}\text { Freshly } \\
\text { graduates }\end{array}$ & 56 & 13 & 5 & 9 & 11 & 6 & 0 & 0 & & & & \\
\hline Postgraduates & 59 & 16 & 6 & 3 & 11 & 5 & 0 & 0 & & & & \\
\hline \multicolumn{13}{|c|}{ DASS 21 Anxiety level } \\
\hline Undergraduates & 67 & 19 & 9 & 3 & 0 & 2 & 0 & 0 & \multirow[t]{3}{*}{0.927} & \multirow[t]{3}{*}{0.169} & \multirow[t]{3}{*}{0.151} & \multirow[t]{3}{*}{6.439} \\
\hline $\begin{array}{l}\text { Freshly } \\
\text { graduates }\end{array}$ & 64 & 20 & 8 & 8 & 0 & 0 & 0 & 0 & & & & \\
\hline Postgraduates & 66 & 20 & 10 & 4 & 0 & 0 & 0 & 0 & & & & \\
\hline \multicolumn{13}{|c|}{ DASS 21 stress level } \\
\hline Undergraduates & 61 & 14 & 14 & 8 & 1 & 2 & 0 & 0 & \multirow[t]{3}{*}{0.841} & \multirow[t]{3}{*}{0.044} & \multirow[t]{3}{*}{1.419} & \multirow[t]{3}{*}{9.796} \\
\hline $\begin{array}{l}\text { Freshly } \\
\text { graduates }\end{array}$ & 55 & 15 & 16 & 13 & 1 & 0 & 0 & 0 & & & & \\
\hline Postgraduates & 62 & 20 & 12 & 4 & 2 & 0 & 0 & 0 & & & & \\
\hline \multicolumn{13}{|c|}{ IES Revised Score } \\
\hline Undergraduates & 32 & 11 & 16 & 2 & 5 & 1 & 23 & 10 & \multirow[t]{3}{*}{0.525} & \multirow[t]{3}{*}{0.679} & \multirow[t]{3}{*}{5.146} & \multirow[t]{3}{*}{3.985} \\
\hline $\begin{array}{l}\text { Freshly } \\
\text { graduates }\end{array}$ & 37 & 9 & 10 & 5 & 3 & 0 & 22 & 14 & & & & \\
\hline Postgraduates & 36 & 10 & 8 & 5 & 3 & 1 & 29 & 8 & & & & \\
\hline
\end{tabular}

While table 6 shows the majority of students had severely affected due to psychological distress and most of the female students had more psychological distress who was in the post-graduate category while freshly graduated males had severe distress due to the corona out-break.

\section{DISCUSSION}

The main aim of the present study was to explore the level of depression, anxiety, and stress among college-going students and those who just passed out from the colleges. The data was collected from different professional filed including medical, modern medicine, engineering, Management, and Nursing. The study was conducted in two different phases in which 948 students were examined first and then only 300 random data were analyzed based on students' level of graduation in three different groups. We examined whether age, gender, location, and highest graduation of the students were related to psychological distress and a negative impact on their mental health or not. In the present study majority of the students did not report any depression, anxiety, and stress-related symptoms which indicates they have good mental health and had a good resilience capacity after this event occurred. Overall $75.5 \%, 87.4 \%$, and $79.9 \%$ of all respondents reported no symptoms of depression, anxiety, and depression. This finding could be due to the closure of universities and colleges. But $13.8 \%$ of participants reported moderate depression, $11.6 \% \& 18.2 \%$ were reported mild anxiety and stress level. $30.8 \%$ of respondents rated severe psychological distress, $14.3 \%$ rated mild and $49.7 \%$ rated normal which shows half of the respondents were having a negative impact of the outbreak of coronavirus. The prevalence rate of severe or mild psychological impact as measured by the IES revised scale was higher than the prevalence of depression, anxiety, and stress as measured by the DASS-21 scale. Since IESRevised assess the psychological distress after an event which was the difference between IES-Revised and DASS 21 scale. Apart from other variables, gender was the only factor that was highly associated with psychological distress and mental health among college-going students. In the present study, we have compared the prevalence rate of female and male respondents of their mental health and 
psychological distress. The level of depression was moderate in both gender in the remaining two-thirds of the population of the students \& the level of anxiety and stresses were mild in both the gender. Even female students were associated with experiencing severe psychological distress in comparison to male respondents. We noted that students who were 22-23 years old and studied in undergraduate having moderate depression levels but the rate of the female population was higher than males in 22-23 age categories but the rate of anxiety was higher in 20-21-year-old females participants. This finding could be because the rate of depressive symptoms was higher in females at the age of 15 and it constantly rises \& doesn't change for the next 35 to 40 years ${ }^{[15]}$. The reason behind these depressive symptoms can be behavioral changes in both the gender as in one study females displayed more sensitivity to an interpersonal relationship between the age of 14-25 whereas men displayed more sensitivity to career and goal-oriented factors ${ }^{[16]}$. First and secondyear undergraduate students had a higher score than those in other year students in the level of depression, anxiety, and stress ${ }^{[17]}$. and these finding are now supporting our results as in 20-21 and 22-23-year-old students had an experienced of mild to a moderate score of depression, anxiety and stress level than the other age categories of the students. As gender is highly associated with depression, anxiety, and stress plus psychological distress, we found that the rate of depression was moderate in female students compared to male participants in the age of 22-23 year older-aged group but the mild anxiety \& stress were higher in 2021-year-old \& 22-23-year-old female respondents compared to male participants. But in contrast, the male respondents aged 20-21-year-old \& 22-23 year old having a severe rate of psychological distress in comparison to female participants.

Another finding in our study was that compared with those in an urban area and those outside urban areas, Respondents in the urban area reported a high prevalence rate of psychological distress. The main reason behind the higher rate of psychological distress in the students who live in the urban area that is lack of adequate infrastructure as the population of urbanization increases which can lead to the risk of poverty \& decreases social support as nuclear families increase in number, due to lockdown \& fear of getting infected as several populations are more in urban compared to rural areas ${ }^{[18]}$.

Previous studies show that with a significant association of stress score with increasing age, Neimi and Vainiomaki reported that the level of stress increased progressively during the course to reach as high as $40 \%$ by the end of the medical course ${ }^{[19]}$ but contradictory to this finding, other studies concluded that the prevalence of stress was decreased as the students progressed in their years of study ${ }^{[20]}$ and this contradictory result was obtained in our study too which shows undergraduate students had reported moderate depression and mild anxiety \& stress levels in comparison to post and freshly graduate students But the number of respondents was high in the undergraduate category. So to make results more generalized we have randomly selected 100 respondents data from three main categories i.e. undergraduates, freshly graduates, and postgraduates. This was phase 2 of our study in which we obtained that freshly graduated students had an unpleasant experience of moderate depression among students whereas the postgraduates and undergraduates students distressed a mild depression. The rate of mild anxiety and stress level was reported in freshly graduate students but the number of students exploited high in freshly graduated in comparison to postgraduates \& undergraduates students due to the negative impact of lockdown on the economy of the country and economy has reduced up to $49 \%$ since 2013 \& unemployment has been increased to $19 \%$ after a month of lockdown but generally, overall unemployment was 
Nijal Parmar et.al. The detrimental effect of depression, anxiety \& stress on under-graduates, post-graduates, and freshly graduates students and their psychological distress triggered by COVID-19 crisis.

$26 \%$ reduced by 24 th of April ${ }^{[21]}$. But only 4 participants had a severe depression level in the undergraduate category of students in both the gender but only 2 male participants had an experienced of moderate anxiety in compare to female respondents out of 76 total male students, whereas 4 female respondents who were in post-graduation course had a moderate stress level compared to other graduates but 2 undergraduate male students reported a moderate stress level among 76 total male participants. As psychological distress was high compared to depression, anxiety, and stresses score in 300 participants, the rate of the severe score of psychological distress was higher in postgraduates female participants \& freshly graduates male participants among 300 total students. The author studied that students should learn deep breathing exercises, relaxation techniques, and mediation plus yoga which can help to calm down their emotions \& reduces the rate of negative psychological impact on their mental health, even they should learn good communication with parents \& friends which helps in a negative mindset and built a positivity ${ }^{[22]}$.

\section{CONCLUSION}

According to phase 2 of the study, the COVID 19 outbreak was associated with mild to moderate depression, anxiety, and stress among college and just passed out students but the majority of students didn't face any symptoms related to mental health whereas half of the students were highly affected due to the outbreak of COVID-19 $\&$ had a severely negative impact on their psychological state of students as their IESrevised score was very high and the majority of post-graduated females and freshly graduated male respondents had affection in their mental health and negative impact of psychological distress.

\section{Acknowledgement: None}

Conflict of Interest: No conflict of interest for this study.
Source of Funding: There was no source of funding as it was self funded by authors

\section{Ethical Approval: Approved}

\section{REFERENCES}

1. Gautam, R. and M. Sharma, 2019-nCoV Pandemic: A disruptive and stressful atmosphere for Indian academic fraternity. Brain Behav Immun, 2020.

2. Hamouche, S., COVID-19 and employees' mental health: stressors, moderators and agenda for organizational actions. Emerald Open Research, 2020. 2: p. 15.

3. Rehman, U., et al., Depression, Anxiety and Stress Among Indians in Times of Covid-19 Lockdown. Community Ment Health J, 2020.

4. Parmar, N. and C. Bodar, How the lockdown can affect mental health among general population in India? A web-based survey. International Journal of Scientific Research, 2020.

5. Goothy, S.S.K., et al., COVID-19 lockdown impact on the mental health of students: need to start a mental health cell. MOJ anatomy \& physiology, 2020.

6. Grubic, N., S. Badovinac, and A.M. Johri, Student mental health in the midst of the COVID-19 pandemic: A call for further research and immediate solutions. Int $\mathrm{J}$ Soc Psychia-try, 2020. 66(5): p. 517-518.

7. Fatima, A. and U. raj, Stress in students after lockdown due to COVID-19 thereat and The effects of attending online classes. SSRN, 2020.

8. TimesNowIndia. UGC Guidelines for University Exams 2020 released - terminal/ final year exams to be conducted by end of Sept. 2020; Available from: https://www.timesnownews.com/education/ article/ugc-exam-guidelines-2020-releasedfinal-year-exams-mandatory-thoughpostponed-new-guidelinesexplained/617386.

9. TheEconomicTimes. COVID-19 to delay job interviews; impact hiring: Experts 2020; Available from: https://economictimes.indiatimes.com/jobs/c ovid-19-to-delay-job-interviews-impacthiring experts/articleshow/74757861.cms?utm_sourc $\mathrm{e}=$ contentofinterest\&utm_medium=text\&ut m_campaign=cppst. 
Nijal Parmar et.al. The detrimental effect of depression, anxiety \& stress on under-graduates, post-graduates, and freshly graduates students and their psychological distress triggered by COVID-19 crisis.

10. Rajkumar, R.P., Suicides related to the COVID-19 outbreak in India: A pilot study of media reports. Asian J Psychiatr, 2020. 53: p. 102196.

11. Lovibond, S.H. and P.F. Lovibond, DASS21. Manual for the Depression Anxiety Stress Scales (2nd ed.). Sydney: DASS Publications., 1995.

12. Hyer, K. and L.M. Brown, The Impact of Event Scale- Revised: A quick measure of a patient's response to trauma. AJN The American Journal of Nursing, 2008. 108(11): p. 60-68.

13. institute, b.d. DASS 21. Available from: www.blackdoginstitute.org.au.

14. Beck, J.G., et al., The impact of event scalerevised: psychometric properties in a sample of motor vehicle accident survivors. J Anxiety Disord, 2008. 22(2): p. 187-98.

15. Cyranowski, J.M., et al., Adolescent onset of the gender difference in lifetime rates of major depression: a theoretical model. Arch Gen Psychiatry, 2000. 57(1): p. 21-7.

16. Kendler, K.S. and C.O. Gardner, Sex differences in the pathways to major depression: a study of opposite-sex twin pairs. Am J Psychiatry, 2014. 171(4): p. 426-35.

17. Bayram, N. and N. Bilgel, The prevalence and socio-demographic correlations of depression, anxiety and stress among a group of university students. Soc Psychiatry Psychiatr Epidemiol, 2008. 43(8): p. 66772.

18. Srivastava, K., Urbanization and mental health. Ind Psychiatry J, 2009. 18(2): p. 756.

19. Niemi, P.M. and P.T. Vainiomaki, Medical students' distress--quality, continuity and gender differences during a six-year medical programme. Med Teach, 2006. 28(2): p. 136-41.

20. Saipanish, R., Stress among medical students in a Thai medical school. Med Teach, 2003. 25(5): p. 502-6.

21. Aritra Ghosh, S.N., Tapas K. Mallicka, How India is dealing with COVID-19 pan-demic. Sensors International, 2020.

22. Liu, X.a.L., Jiaxiu and Zhong, Xiaoni, Psychological State of College Students During COVID-19 Epidemic SSRN electronic journal, 2020.

How to cite this article: Parmar N, Kasundra V, Vaghasiya A et.al. The detrimental effect of depression, anxiety \& stress on under-graduates, post-graduates, and freshly graduates students and their psychological distress triggered by COVID-19 crisis. International Journal of Research and Review. 2021; 8(4):37-46. DOI: https://doi.org/10.52403/ijrr.20210407 